\title{
Determination of anticancer effects of Urospermum picroides against human cancer cell lines
}

\author{
Mehlika Alper (i) 1, Hatice Güneş (iD*,2
}

\author{
${ }^{1}$ Muğla Sitkı Koçman University, Science Faculty, Department of Molecular Biology and Genetics, 48000, Muğla, \\ Turkey \\ ${ }^{2}$ Muğla Sitkı Koçman University, Science Faculty, Department of Biology, Division of Molecular Biology and \\ Biotechnology, 48000, Muğla, Turkey
}

\begin{abstract}
Plants continue to be a good source for developing effective anticancer agents. In this study, in vitro various biological effects of crude ethanolic extract from flowering parts of Urospermum picroides collected from the Muğla province of Turkey were investigated for the first time. Daudi, A549 and HeLa cancer cell lines and BEAS-2B normal cell line were used to identify the cytotoxic effect of the extract using MTT assay. The effect of the extract on cell cycle progression was detected by flow cytometric analysis. The level of VEGF, IL- $1 \alpha$, IL- 6 and TNF- $\alpha$ secretion in the cells treated with the extract were measured using ELISA The extract caused a higher cytotoxic effect on Daudi cells with an $I C_{50}$ value of $85.64 \mu \mathrm{g} / \mathrm{mL}$ than the other cells tested. The $I C_{50}$ values in HeLa and A549 cells were determined to be 135.35 and $234.8 \mu \mathrm{g} / \mathrm{mL}$, respectively. The selective cytotoxicity was considered between Daudi and BEAS-2B $(109.80 \mu \mathrm{g} / \mathrm{mL})$ cell lines. In addition, the effect of the extract on cell cycle progression changes according to cell line used. Moreover, the extract decreased the level of secreted VEGF in treated A549 cells by $31 \%$. In addition, the extract resulted in a significant decrease in the secretion of IL-1 $\alpha$, IL- 6 and TNF- $\alpha$ cytokines in A549 and Daudi cells compared to the untreated cells. These findings suggest that the flowering parts of $U$. picroides may be a potential source for anticancer agents.
\end{abstract}

\section{ARTICLE HISTORY}

Received: November 13, 2018

Revised: January 03, 2019

Accepted: January 16, 2019

\section{KEYWORDS}

Urospermum picroides,

Cytotoxicity,

Cell cycle analysis,

Cancer cell lines

\section{INTRODUCTION}

Cancer is an important health problem around the globe and significantly contributes to human deaths. The annual number of new cancer cases are increasing estimated to be 21.6 million by 2030 [1].

Because the drugs used for the treatment of cancer can cause serious side effects [2], it is important to develop new-selective anticancer agents. Plants have been used for treating various diseases throughout the ages and they continue to be a critical source of potent anticancer agents

${ }^{*}$ CONTACT: Hatice Güneş $\varangle$ haticegunes@mu.edu.tr $\equiv$ Department of Biology, Division of Molecular Biology and Biotechnology, Muğla Sitkı Koçman University, Kötekli Campus, 48000 Muğla, Turkey

Tel. +90252 211 1530; Fax. +90252 2231472 
due to their contents [3]. Some of the plant derived compounds such as vincristine, vinblastine and paclitaxel are still used as chemotherapeutic agents in clinical cancer treatment [4]. Therefore, the anticancer potentials of the plants are being investigated all over the world to obtain new agents.

Urospermum picroides (L.) SCOP. ex. F. W. Schmidt is a species of the Asteraceae family [5] and also known as prickly golden fleece [6]. It belongs to the traditional Mediterranean diet and has anti-inflammatory activity [7]. The consumption of this plant was reported to reduce postprandial platelet aggregation in metabolic syndrome patients [8]. Previous studies demonstrated the antioxidant and antimicrobial activity $[9,10]$ of this species as well as its phytochemical content $[11,12]$ with potential biological properties. However, to our knowledge, there is no detailed study in the literature about the different biological activities of $U$. picroides. So, for the first time we aimed to determine the various biological effects of ethanolic extract from flowering parts of $U$. picroides on different cancer cell lines.

\section{MATERIALS AND METHODS}

\subsection{Collection and extraction of plant material}

$U$. picroides were harvested from Muğla province, Turkey, in the between June and July 2014. The plant species was identified by Dr. Fatma Güneş at the Department of Pharmaceutical Botany, Trakya University, Edirne. The voucher specimen was kept in their herbarium.

The fresh flowering parts of plant were firstly washed with the deionized water and air dried at room temperature under shade for about 15 days. The dried flowers were powdered and each 10 grams powder were extracted with $100 \mathrm{~mL}$ absolute ethanol (Merck, USA) using soxhlet apparatus for $10 \mathrm{~h}$. The extract was then filtered through Whatman filter paper no: 1 and solvent was separated from the extract using a rotary evaporator (IKA, RV 10, USA). The ethanolic crude extract of $U$. picroides was stored at $-20^{\circ} \mathrm{C}$ in polyethylene tubes protected from light-until needed.

\subsection{Cell culture conditions}

A549 (lung adenocarcinoma), HeLa (cervix adenocarcinoma), Daudi (Burkitt's lymphoma) and BEAS-2b (normal bronchial epithelium) human cell lines were obtained from ATCC. The cell lines were grown in RPMI 1640 (Biochrom, Germany) medium with stable Lglutamine (Biochrom, Germany) contained 10\% heat inactivated fetal bovine serum (FBS) (Biochrom, Germany) supplemented with 100 units $/ \mathrm{mL}$ penicillin and $100 \mathrm{mg} / \mathrm{mL}$ streptomycin (Biochrom, Germany). All cell cultures were incubated at $37^{\circ} \mathrm{C}$ in a humidified atmosphere with $5 \% \mathrm{CO}_{2}$ and $95 \%$ air.

\subsection{Cytotoxic assay}

MTT [ 3 (4, 5 Dimethyl-2-thiazolyl)-2, 5 diphenyl-2H-tetrazolium bromide) ] (Applichem, USA) assay [13] was used for determination of cytotoxicity of the extract on cell lines used in present study. The assay is based on the reduction of yellow tetrazolium salt MTT to purple formazan crystal by mitochondrial dehydrogenase in the viable cells [14]. Briefly, the exponentially growing cells were seeded at a density of $4 \times 10^{3}$ cells per well in $180 \mu \mathrm{L}$ of growth medium into 96-well plates (Greiner, Germany) as triplicate for each tested extract concentration. After $24 \mathrm{~h}$ of incubation, the cells were treated with the extract at different final concentrations ( 15.625 to $1000 \mu \mathrm{g} / \mathrm{mL}$ ) for $72 \mathrm{~h}$. The stock solution of the extract was prepared in $10 \%$ DMSO (Applichem, USA) in growth medium and diluted with growth medium to obtain serial dilutions. So, the cells were exposed to DMSO at less than $0.1 \%$ of the final concentration. The untreated cells were used as a control. Later, the medium was removed and $100 \mu \mathrm{L}$ of fresh growth medium was added into each well. Then, the cells in each well were incubated with 10 $\mu \mathrm{L}$ of $5 \mathrm{mg} / \mathrm{mL}$ MTT in phosphate-buffered saline (PBS) for $4 \mathrm{~h}$ at $37^{\circ} \mathrm{C}$. At the end of $4 \mathrm{~h}$, the 
medium with MTT was gently discarded from the wells and formazan crystals formed in the cells were solubilized with $100 \mu \mathrm{L}$ of DMSO by shaking at $150 \mathrm{rpm}$ for $5 \mathrm{~min}$. The absorbance (Abs) measurement of reduced MTT in each well was made at $540 \mathrm{~nm}$ using a microplate reader (ThermoScientific, Multiscan FC, USA). The following formula was used to calculate the percentage of cell viability for each concentration.

$$
\text { Cell viability \%= (Mean Abs of treated cells/Mean Abs of untreated cells) } x 100
$$

\subsection{Cell cycle analysis}

Cell cycle detection in A549 and HeLa cells was performed by propidium iodide (PI) (Sigma-Aldrich, USA) staining using flow cytometry. Firstly, the cells were seeded at $5 \times 10^{5}$ cells/well in 6-well plates and incubated for $24 \mathrm{~h}$. Then, the cells were exposed to 500 and 200 $\mu \mathrm{g} / \mathrm{mL}$ extract for $24 \mathrm{~h}$. DMSO at $1 \%$ final concentration was used as a control. After treatment, cells were harvested by trypsinization, washed with cold PBS twice, fixed gently in absolute ethanol and stored at $-20^{\circ} \mathrm{C}$ for $48 \mathrm{~h}$. After centrifugation at $1200 \mathrm{rpm}$ for $10 \mathrm{~min}$ at $4{ }^{\circ} \mathrm{C}$, cell pellets were washed with cold PBS and resuspended in $1 \mathrm{~mL} 0.1 \%(\mathrm{v} / \mathrm{v})$ Triton X-100 (Amresco, USA) in PBS. Then, cell suspensions were treated with $100 \mu \mathrm{L}$ of RNase A (200 $\mu \mathrm{g} / \mathrm{mL}$ ) (Applichem, USA) and incubated at $37^{\circ} \mathrm{C}$ for $30 \mathrm{~min}$. Finally, $100 \mu \mathrm{L}$ of PI $(1 \mathrm{mg} / \mathrm{mL})$ was added to each cell suspensions and cells were incubated for additional $15 \mathrm{~min}$ at room temperature in the dark. After staining, cells were analysed for cell cycle phases by BD FACSCanto flow cytometry (BD Biosciences, San Jose, CA) using ModFit LT 3.0 software.

\subsection{Enzyme-linked immune sorbent assay (ELISA)}

The supernatants of the cell cultures were used for quantification of Vascular endothelial growth factor (VEGF) in A549 and for quantification of cytokines (IL-1 $\alpha$, IL-6 and TNF- $\alpha$ ) in both A549 and Daudi by using commercial human ELISA kits (Boster Biological Technology, USA). To obtain supernatants, cells were seeded in a 6 well-plate at a density of $2 \times 10^{5}$ cells/well. After $1 \mathrm{~h}$ incubation at $37^{\circ} \mathrm{C}$ in $\mathrm{CO}_{2}$ incubator, cells were treated with extract at 200 $\mu \mathrm{g} / \mathrm{mL}$ for $6 \mathrm{~h}$. The untreated cells were used as a control. Later, supernatants were collected from treated and untreated cells and centrifuged at $14000 \mathrm{rpm}$ for 30 seconds. The obtained supernatants were aliquoted and stored at $-20^{\circ} \mathrm{C}$ until use. A $100 \mu \mathrm{L}$ of supernatant was analysed for VEGF or inflammatory each cytokine production via ELISA kits according to the manufacturer instructions. The absorbance in each well was read at a wavelength of $450 \mathrm{~nm}$ using a microplate reader. The level of secreted VEGF or each cytokine was interpolated from the standard curve prepared separately for each assay.

\subsection{Statistical analysis}

The results obtained from in this study were expressed as mean \pm standard error (SE). Statistical analysis and data processing were performed by using GraphPad Prism 7.0 (GraphPad Software, Inc., San Diego, CA).

\section{RESULTS}

\subsection{Cytotoxic effect of the extract on different cell lines}

The effect of the extract on cell viability was investigated on A549, HeLa, Daudi and BEAS-2B cell lines for $72 \mathrm{~h}$ by MTT assay. The extract was prepared at seven serial concentrations from 1000 to $15.625 \mu \mathrm{g} / \mathrm{mL}$ and tested against the cell lines used. The $I C_{50}$ values $(\mu \mathrm{g} / \mathrm{mL})$ that causes $50 \%$ cell death were then calculated for each cell lines. As shown in Figure 1, cell viability, particularly in cancer cell lines was significantly inhibited by the extract in a concentration-dependent manner. However, the results showed that the extract at 15.625-62.5 $\mu \mathrm{g} / \mathrm{mL}$ concentrations were less cytotoxic on normal BEAS-2B cells when compared to cancer cells tested. The extract exhibited the higher cytotoxicity against Daudi 
cells with an $I C_{50}$ value of $85.64 \mu \mathrm{g} / \mathrm{mL}$ when compared to normal BEAS-2B cells $\left(I C_{50}\right.$ value $=$ $109.8 \mu \mathrm{g} / \mathrm{mL}$ ) and other cancer cells. The calculated $I C_{50}$ values were 234.8 and $135.35 \mu \mathrm{g} / \mathrm{mL}$ for A549 and HeLa, respectively. So, Daudi cell lines were found to be the most sensitive line to the extract.
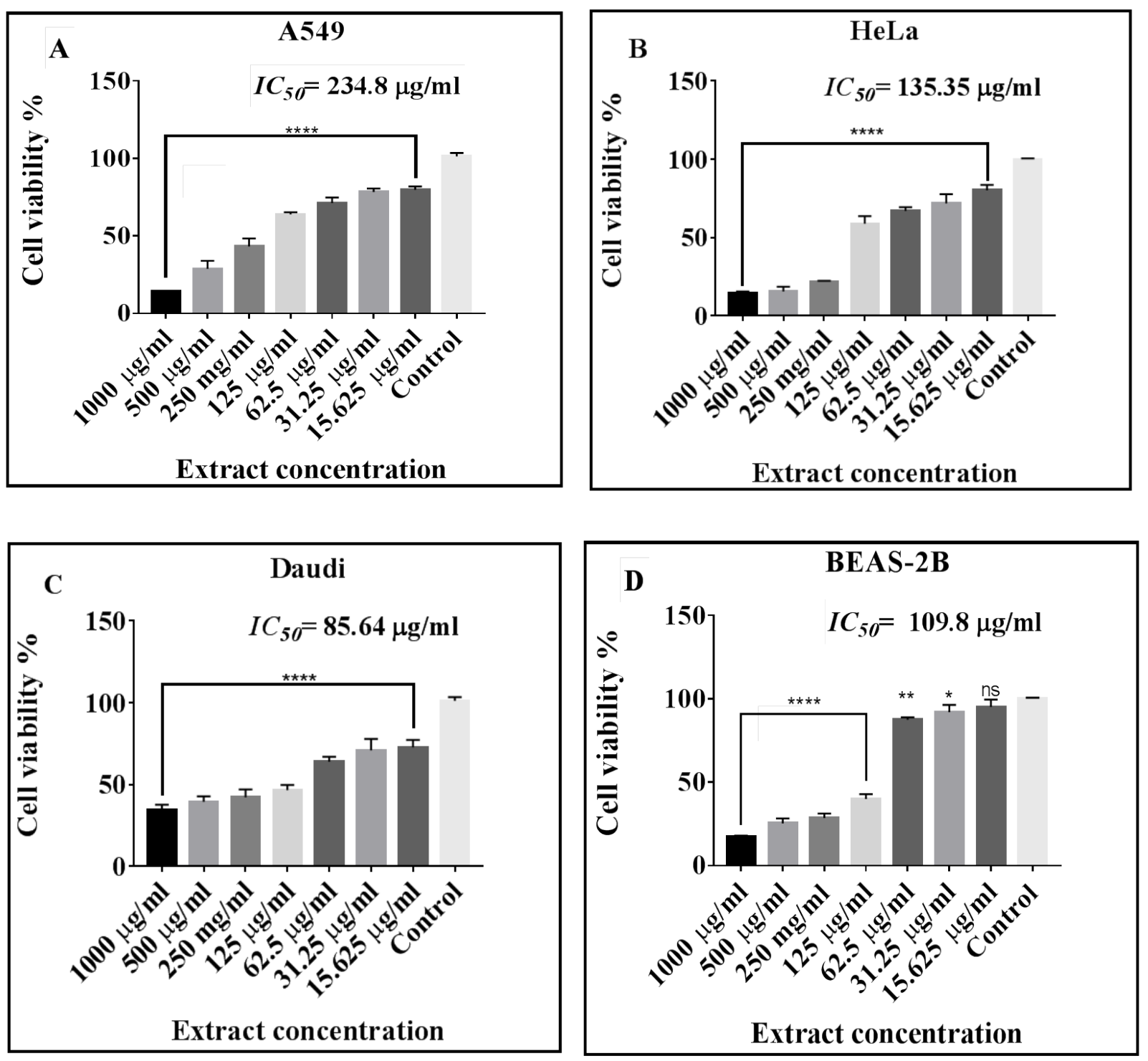

Figure 1. Cytotoxic effects of ethanol extract of flowering parts of $U$. picroides against A549 (A), HeLa (B), Daudi (C) and BEAS-2B (D) cell lines after an exposure time of $72 \mathrm{~h}$. Cell viability was determined using MTT assay. The data represent mean \pm SE of three independent experiments for each concentration. $* * * * P<0.0001, * * P<0.01, * P<0.05$ and ns: non-significant $(P>0.05)$ compared to control (ANOVA and Tukey's multiple comparison test).

\subsection{Effect of the extract on cell cycle progression in A549 and HeLa cell lines}

The flow cytometry analysis was performed to investigate cell cycle progression in A549 and HeLa cancer cells after treatment with extracts at 500 and $200 \mu \mathrm{g} / \mathrm{mL}$ for $24 \mathrm{~h}$ (Figure 2). The treatment with $500 \mu \mathrm{g} / \mathrm{mL}$ extract showed $5.97 \%$ and $9.72 \%$ increases of A549 cells in G2 and $\mathrm{S}$ phase compared to control, respectively and there was a concomitant decrease in the percentage of A549 cells in the G1 phase. The percentage of A549 cells in G2 phase after treatment with extract at $200 \mu \mathrm{g} / \mathrm{mL}$ significantly increased from 4.82 to 25.81 and it was accompanied by a decrease in the percentage of cells in G1 and S phase. In addition, the percentage of HeLa cells in G1 phase increased from 48.97 to 59.00 after treatment with the 
extract at $500 \mu \mathrm{g} / \mathrm{mL}$ and there was a sharp decrease in the percentage of G2 and S phase. On the other hand, the treatment of HeLa cells with $200 \mu \mathrm{g} / \mathrm{mL}$ extract resulted in $4.19 \%$ and $5.06 \%$ increase of cells in S and G2 phase, respectively. These data demonstrated that the plant extract affect the cell cycle progression in the different phases according to the type of cell line tested.

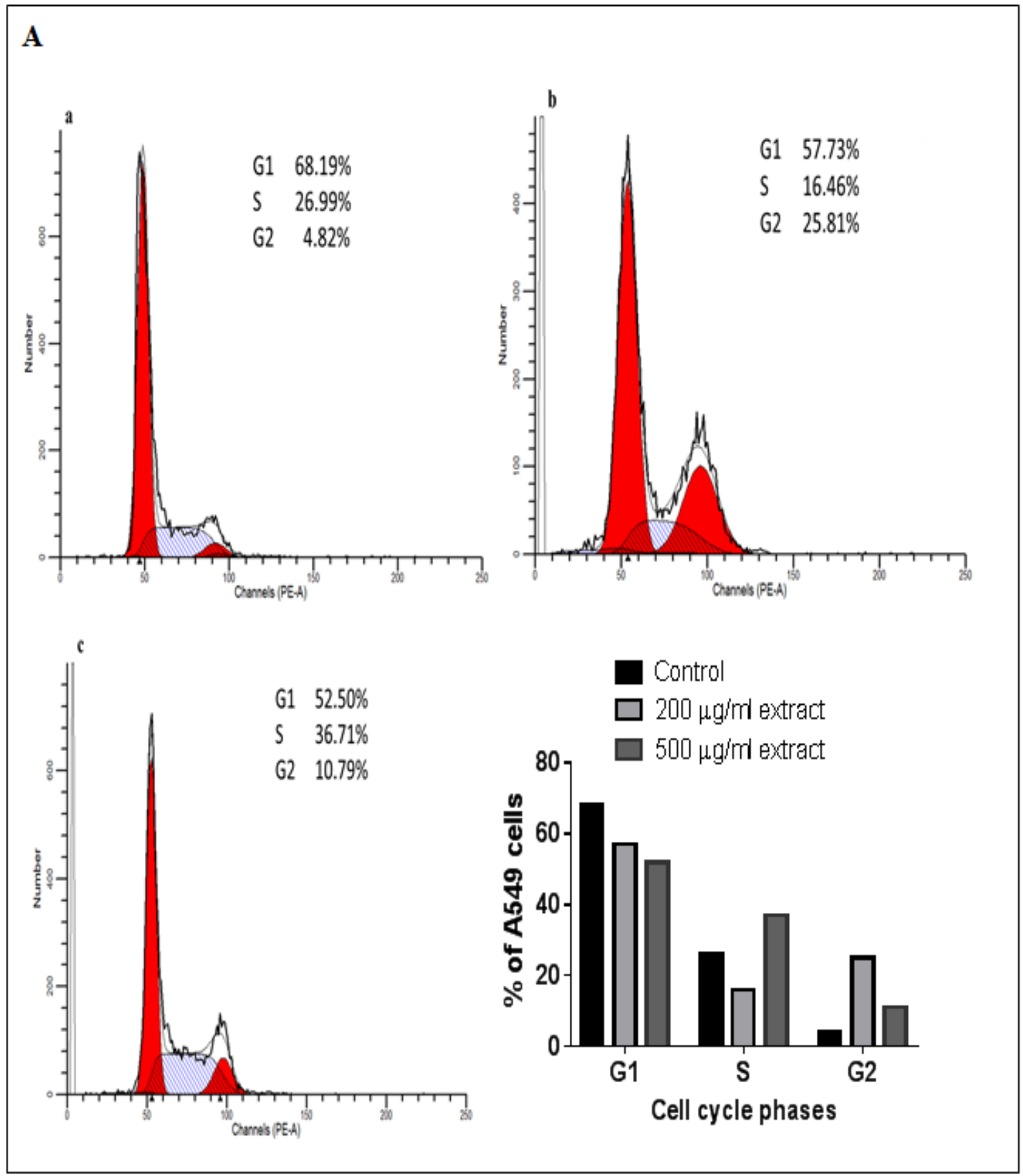




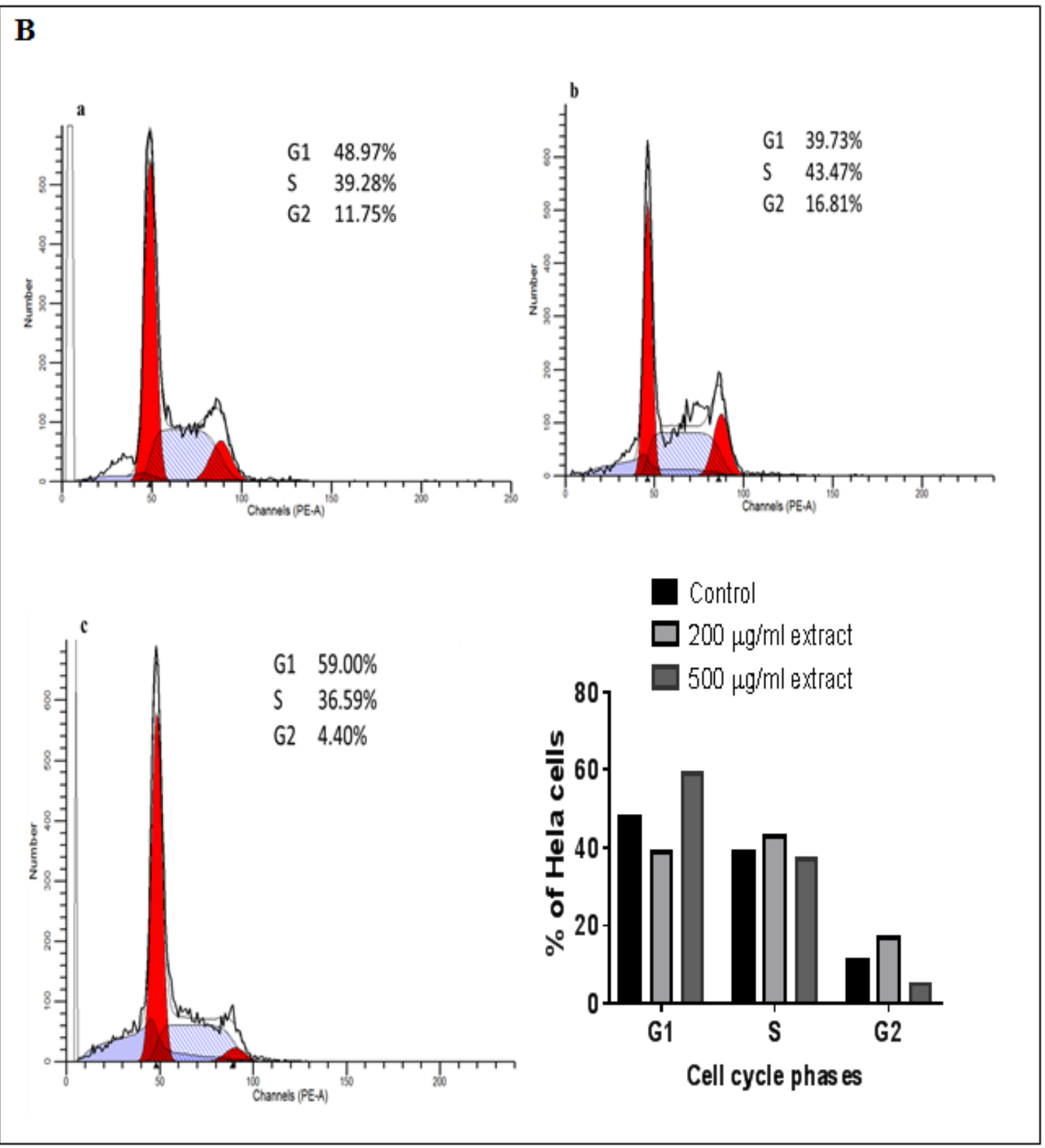

Figure 2. Effects of the extract on cell cycle distribution in A549 and HeLa cells. A549 (A) and HeLa (B) cells treated with 1\% DMSO as control (a), 200 (b) and 500 (c) $\mu \mathrm{g} / \mathrm{mL}$ extract for $24 \mathrm{~h}$. Bar graph with percentages of cells at different cell cycle phases are shown (d).

\subsection{Effect of the extract on VEGF secretion}

It was reported that A549 cells released VEGF [15]. In this study, we investigated the VEGF levels in supernatants of A549 cell culture using human VEGF ELISA assay. Our findings showed that VEGF secretion was reduced by $31 \%$ in A549 cells treated with 200 $\mu \mathrm{g} / \mathrm{mL}$ extract compared to untreated cells (Figure 3). This result indicate that the extract has antiangiogenic potential against A549 cells because the VEGF is an angiogenic factor [16]. 


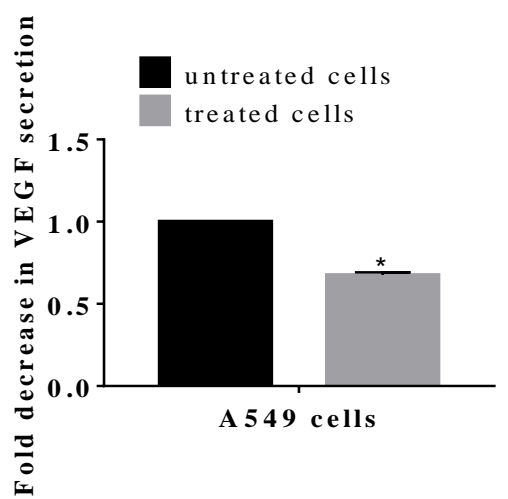

Figure 3. Effects of the extract on VEGF secretion of A549 cells. The VEGF concentration in supernatants of A549 cells treated with the extract at $200 \mu \mathrm{g} / \mathrm{mL}$ for $6 \mathrm{~h}$ was determined by ELISA. The values represent the mean of three independent experiments \pm SE. The concentration of VEGF in control (untreated) cells is taken as 1 -fold. The asterisks indicate statistical significance when compared to untreated cells. $* P<0.05$

\subsection{Effect of the extract on secretion of IL-1 $\alpha$, IL-6 and TNF- $\alpha$ cytokines}

In this study, we also investigated the effect of the plant extract at $200 \mu \mathrm{g} / \mathrm{mL}$ on IL- $1 \alpha$, IL-6 and TNF- $\alpha$ secretion in A549 and Daudi cells by using ELISA. The results were graphically shown in Figure 4. The extract did not cause any increase in concentrations of IL$1 \alpha$, IL- 6 and TNF- $\alpha$ cytokines in treated cells compared to untreated cells. The highest inhibition effect of the extract was found in A549 for IL-6 secretion (12\%) and Daudi for IL$1 \alpha$ secretion $(15 \%)$. As a result, the plant extract does not induce secretion of cytokine that can promote cancer development and progression.

A

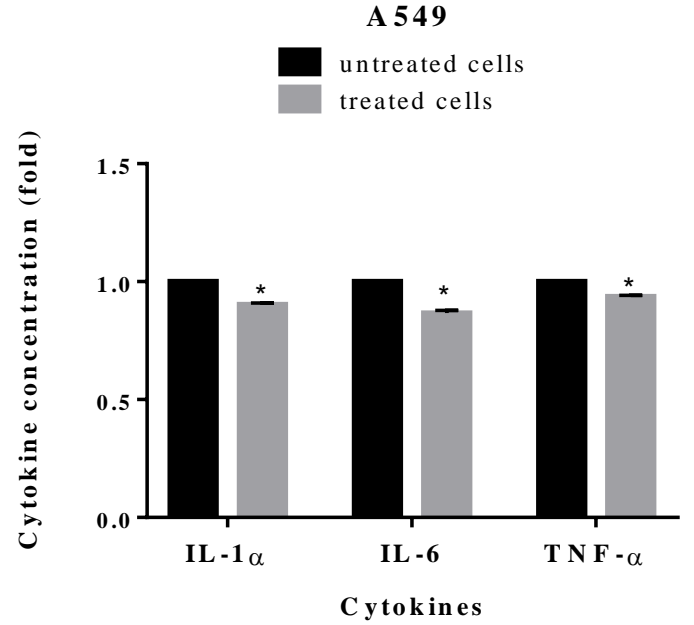

B

D audi

untreated cells treated cells

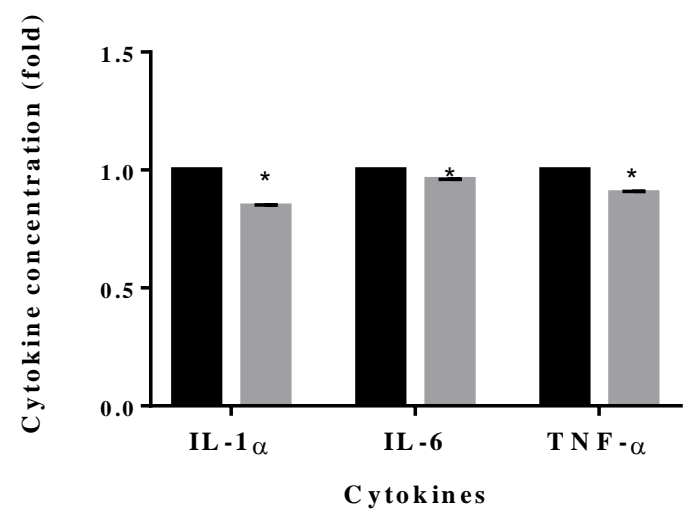

Figure 4. Effects of the extract on IL- $1 \alpha$, IL-6 and TNF- $\alpha$ secretion of A549 (A) and Daudi (B) cells. The cytokines concentration in supernatants of the cancer cells treated with the extract at $200 \mu \mathrm{g} / \mathrm{mL}$ for $6 \mathrm{~h}$ was determined by ELISA. The values represent the mean of three independent experiments $\pm \mathrm{SE}$. Results presented as fold of change in relation to the control (untreated) cells. The asterisks indicate statistical significance when compared to untreated cells. ${ }^{*} P<0.05$. 


\section{DISCUSSION and CONCLUSION}

Cancer is one of the most important diseases that can be fatal worldwide [2]. Because cancer cells can develop drug resistance in traditional therapies [17], the discovery of a new drug with anti-cancer mechanism is of great importance. For centuries, natural products especially plant-derived compounds have an important role in the development of drugs used in the treatment of cancer [18].

It was reported that $U$. picroides was commonly used in the traditional Mediterranean diet [7] and sold in the Dalmatia markets [6]. Interestingly, a significant information was not found that it was a common edible plant in the world.

There are various research studies on the chemical composition of $U$. picroides in the literature [11,12,19,20]. Also, the anti-inflammatory [7], antioxidant and antimicrobial activity $[9,10]$ of $U$. picroides were reported. In addition, Fragpouli et al. [8] stated that the consumption of $U$. picroides meals significantly reduced the ex vivo platelet activating factor-induced platelet aggregation postprandially. However, to our knowledge, the cytotoxic and anti-inflammatory and antiangiogenic activity of ethanolic extract of flowering parts of $U$. picroides collected from Turkey were investigated for the first time on different cancer cell lines.

We first aimed to assess the cytotoxic activity of the extract on different cancer cell lines after treatment for $72 \mathrm{~h}$. The extract was found to exhibit cytotoxicity at the different level according to the type of cell line tested and inhibit the viability of these cells in a dose-dependent manner. Daudi cells with an $I C_{50}$ value of $85.64 \mu \mathrm{g} / \mathrm{mLw}$ as the most sensitive cell lines to the extract. However, the $I C_{50}$ value of the extract against BEAS-2B normal cell line was calculated as $109.80 \mu \mathrm{g} / \mathrm{mL}$. In addition, IC 50 values in HeLa and A549 cells were found to be 135.35 and $234.8 \mu \mathrm{g} / \mathrm{mL}$, respectively. In Egypt, El-Nabawy et al. [9] assessed the cytotoxic activity of different fractions of aerial parts and seeds of $U$. picroides on different cell lines. They reported that the seeds butanol fraction and the aerial parts ethyl acetate fraction were very cytotoxic to MCF-7 (IC 50 value $=9.4 \pm 0.37$ and $8.8 \pm 0.47 \mu \mathrm{g} / \mathrm{mL}$, respectively), and to HePG-2 (IC 50 value= $14.7 \pm 0.85$ and $10.1 \pm 0.88 \mu \mathrm{g} / \mathrm{mL}$, respectively) cells. So, it can be suggested that the different part of $U$. picroides and the type solvent used for extraction may cause cytotoxicity at the different level according to the cell type examined.

One of the hallmarks of cancer is uncontrolled cell division [21]. Because the normal cell regulation process in the human cancer cells are altered [22], it is important to investigate new anti-cancer drugs which can inhibit the different steps of the cell cycle. We examined the effect of the extract on cell cycle for $24 \mathrm{~h}$. Our results showed that the extract caused cell cycle arrest for A549 cells and HeLa cells at different phase of cell cycle. These results indicate that the effect of the plant extract on cancer cell proliferation may occur by arresting the cell cycle.

The development of new blood vessels from pre-existing ones is called angiogenesis and this process is important in the growth and metastasis of cancer tissue [23]. VEGF is known as a key regulator of angiogenesis in cancer [24] so that VEGF is considered as a rational target for anticancer therapy. In the present study, we tested the effect of the extract on the secretion of VEGF in A549 cells after treatment for $6 \mathrm{~h}$. Our results show that the treatment with the extract at $200 \mu \mathrm{g} / \mathrm{mL}$ reduced the level of VEGF secretion by $31 \%$ in A549 cells compared to untreated cells, suggesting the antiangiogenic potential of the extract against A549 cells.

It is known that the inflammatory cytokines play a critical role in tumor development [25]. The pro-inflammatory cytokines such as TNF- $\alpha$, IL-1 and IL-6 may contribute the growth and the metastasis of cancer cells [26]. We finally investigated whether the extract altered the TNF- $\alpha$, IL-1- $\alpha$ and IL- 6 secretion in the A549 and HeLa cells after treatment for $6 \mathrm{~h}$. The treatment with the extract at $200 \mu \mathrm{g} / \mathrm{mL}$ did not cause any increase in the secretion of proinflammatory cytokines examined in cancer cell lines used. Strzelecka et al. [7] investigated the 
anti-inflammatory activity of the extracts of some traditional Mediterranean diet plants and reported that the extracts of plants including $U$. picroides showed promising anti-inflammatory properties. Thus, our results suggest that the plant extract may not promote the development of cancer associated with the pro-inflammatory cytokines.

As a result, this study demonstrated for the first time that the ethanolic extract from the flowering parts of $U$. picroides showed significant cytotoxic activity against different cancer cell lines. Daudi cells were the most sensitive to the extract than the other cells used. The extract resulted in an arrest of A549 and HeLa cells at different phases of cell cycle. In addition, the extract caused a significant decrease in the secretion of cytokines after $6 \mathrm{~h}$ treatment in comparison with the untreated cells. Therefore, these findings may provide an important contribution to obtain a new bioactive compound with anti-cancer potential from the flowering part of $U$. picroides. Future studies should evaluate the determination of the potential of novel agents for cancer therapy via in vivo and in vitro analysis.

\section{Orcid}

Mehlika Alper (iD https://orcid.org/0000-0001-6193-346X

Hatice Güneş (D) https://orcid.org/0000-0001-5191-365X

\section{REFERENCES}

[1]. World Health Organization. World health statistics 2017: monitoring health for the SDGs, Sustainable Development Goals. Geneva: World Health Organization; 2017.

[2]. Unnati, S., Ripal, S., Sanjeev, A., Niyati, A. (2013). Novel anticancer agents from plant sources. Chin J Nat Me., 11, 16-23.

[3]. Cragg, G.M., Newman, D.J. (2013). Natural products: A continuing source of novel drug leads. Biochim Biophys Acta, 1830, 3670-3695.

[4]. Kintzios, S.E. (2006). Terrestrial Plant-Derived Anticancer Agents and Plant Species Used in Anticancer Research. CRC Crit Rev Plant Sci, 25, 79-113.

[5]. Güner, A., Aslan, S., Ekim, T., Vural, M., Babaç, M. T. (2012). Türkiye Bitkiler Listesi (Damarlı Bitkiler). Nezahat Gökyiğit Botanik Bahçesi Yayını, İstanbul, 1290s.

[6]. Łuczaj, L., Zovko Končić, M., Miličević, T., Dolina, K., Pandža, M. (2013). Wild vegetable mixes sold in the markets of Dalmatia (southern Croatia). J Ethnobiol Ethnomed, 9, 1-12.

[7]. Strzelecka, M., Bzowska, M., Kozieł, J., Szuba, B., Dubiel, O., Riviera Núńez, D., Heinrich, M., Bereta, J. (2005). Anti-inflammatory effects of extracts from some traditional Mediterranean diet plants. J Physiol Pharmacol, 56, 139-156.

[8]. Fragopoulou, E., Detopoulou, P., Nomikos, T., Pliakis, E., Panagiotakos, D.B., Antonopoulou, S. (2012). Mediterranean wild plants reduce postprandial platelet aggregation in patients with metabolic syndrome. Metabolism, 61, 325-334.

[9]. El-Nabawy, H.I., Ayyad, D.M., Serag, M.S., Abdel-Mogib, M. (2015). Phytochemical and Biological Evaluation of Urospermum Picroides. Mansoura J Chem, 19-31.

[10]. El-Amier, Y.A., Al-hadithy, O.N., Abdullah, T.J. (2016). Antioxidant and Antimicrobial Activity of Different Extracts Obtained from Aerial Parts of Urospermum picroides (L.) F.W. from Egypt. J Adv Chem Sci, 2, 299-301.

[11]. Giner, R.M., Cuéllar, M.J., Recio, M.C., Máñez, S., Ríos, J.L. (1992). Chemical Constituents of Urospermum picroides. Z Naturforsch, 47c, 531-534.

[12]. Balboul, B.A.A.A., Ahmed, A.A., Otsuka, H. (1997). Sesquiterpene Lactones and Glucosides from Urospermum picroides. Phytochemistry, 45, 369-373.

[13]. Mosmann, T. (1983). Rapid colorimetric assay for cellular growth and survival: Application to proliferation and cytotoxicity assays. J Immunol Methods, 65, 55-63. 
[14]. Denizot, F., Lang, R. (1986) Rapid colorimetric assay for cell growth and survival: Modifications to the tetrazolium dye procedure giving improved sensitivity and reliability. J Immunol Methods, 89, 271-277.

[15]. Koyama, S., Sato E, Tsukadaira A, Haniuda M, Numanami H, Kurai M, Nagai S, Izumi T. (2002). Vascular endothelial growth factor mRNA and protein expression in airway epithelial cell lines in vitro. Eur Respir J, 20, 1449-1456

[16]. Nör, J.E., Christensen J, Mooney DJ, Polverini PJ. (1999) Vascular endothelial growth factor (vegf)-mediated angiogenesis is associated with enhanced endothelial cell survival and induction of bcl-2 expression. Am J Pathol, 154, 375-384.

[17]. Housman, G., Byler, S., Heerboth, S., Lapinska, K., Longacre, M., Snyder, N., Sarkar, S. (2014). Drug Resistance in Cancer: An Overview. Cancers, 6, 1769-1792.

[18]. Cragg, G.M., John M. Pezzuto, J. M. (2016). Natural Products as a Vital Source for the Discovery of Cancer Chemotherapeutic and Chemopreventive Agents. Med Princ Pract, 25, 41-59.

[19]. Metwally, A.M., Saleh, M.R.I., Amer, M.M.A. (1973). Isolation of two flavonoidal principles from Urospermum picroides. Planta Med, 23, 94-98.

[20]. Amer, M.M.A., Salama, O. M., Bohlmann, F., Ziesche, J. (1984). Urospermal, a glucoside from Urospermum picroides. Phytochemistry, 23, 692-693.

[21]. Hanahan, D., Weinberg, R. A. (2011). Hallmarks of Cancer: The Next Generation. Cell, 144, 646-674.

[22]. Shapiro, G.I., Harper, J.W. (1999). Anticancer drug targets: cell cycle and checkpoint control. J Clin Invest, 104, 1645-1653.

[23]. Nishida, N., Yano H, Nishida T, Kamura T, Kojiro M. (2006). Angiogenesis in Cancer. Vasc Health Risk Manag, 2, 213-219.

[24]. Carmeliet P. (2005) VEGF as a key mediator of angiogenesis in cancer. Oncology, 69, 410.

[25]. Coussens, L.M., Werb, Z. (2002) Inflammation and cancer. Nature, 420, 860-867.

[26]. Kuninaka, S., Yano, T., Yokoyama, H., Fukuyama, Y., Terazaki, Y., Uehara, T., Kanematsu, T., Asoh, H., Ichinose, Y. (2000). Direct influences of pro-inflammatory cytokines (IL-1beta, TNF-alpha, IL-6) on the proliferation and cell-surface antigen expression of cancer cells. Cytokine, 12, 8-11. 